\title{
THE GREEN ECONOMY AND POST-GROWTH REGIMES: OPPORTUNITIES AND CHALLENGES FOR ECONOMIC GEOGRAPHY
}

\author{
by \\ Christian Schulz and Ian Bailey
}

SCHULZ, C. and BAILEY, I. (2014): 'The green economy and post-growth regimes: opportunities and challenges for economic geography', Geografiska Annaler: Series B, Human Geography 96 (3): $277-291$.

ABSTRACT. While mainstream economic geography is doing increasing research on green manufacturing and services, with a few notable exceptions, its predominant conceptual approaches to emerging modes of economic orientation continue to examine economic transitions somewhat unreflexively within the context of traditional growth paradigms. The aim of this article is to explore and critically examine neoliberal discourses on the green economy and smart growth by exploring contributions to debates on green economics proposed by ideas linked to post-growth economies. Based on studies by scholars such as Tim Jackson and Serge Latouche, the article examines the contours of debates on post-growth, décroissance (de-growth) and prosperity without growth. We begin by examining growth debates and existing contributions by economic and other geographers to the exploration of alternatives to conventional growth-centred economics. We then identify some emergent spatial facets of post-growth transitions and utilize these to explore potential research topics and opportunities for empirical and conceptual contributions by economic geographers to academic and societal debates on economic transitions and post-growth paradigms. Particular attention is paid to approaches currently discussed in economic geography, such as socio-technical transition studies.

Keywords: environmental economic geography, green growth, post-growth, décroissance/de-growth, transitions towards sustainability

\section{Introduction}

A crucial question facing the collection of ideas and initiatives clustering around the green economy is their stance towards economic growth (Davies and Mullin 2011; Jackson 2011; Kosoy et al. 2012). In essence, to what extent are continued commitments to existing or modified growth orientations reconcilable with green economy ideals or is deeper questioning of traditional growth concepts required? The United Nations Environmental Programme (UNEP 2011 , p. 16) remains somewhat ambiguous on the issue, preferring instead to emphasize the green economy's contribution to poverty reduction, equity and environmentally centred growth:
A green economy is low-carbon, resource efficient, and socially inclusive. In a green economy, growth in income and employment are driven by public and private investments that reduce carbon emissions and pollution, enhance energy and resource efficiency, and prevent the loss of biodiversity and ecosystem services.

Other observers are less guarded about associating the green economy with largely conventional, growth-centred capitalism, and criticize the concept for ignoring demand-side issues and reproducing concepts that create new avenues and arenas for wealth accumulation that may only coincidentally address environmental and social concerns (Kosoy et al. 2012; Newell 2012). Caprotti (2012) similarly observes how front-line actors like cleantech investors are utilizing discursive logics that emphasize resource efficiency, growth and profit maximization in order to establish their identity and fuel capital towards technological responses to environmental issues. Attempts by city-regions and countries to establish leadership in green-economy innovation as a means of stimulating growth (Davies and Mullin 2011; Gibbs and O'Neill 2014) further reinforce the view that the main currents of green-economy thinking are flowing towards new portrayals of economic growth, but towards economic growth nevertheless.

The central aim of this article is to explore the ways in which economic geography as a subdiscipline can contribute to debates on notions of growth and alternative economic models - including those associated with post-growth - as part of the wider complex of debates on the green economy. In so doing, we argue that economic geographers need to be more energetic and critical in appraising the orientations and impacts of the various "green stimulus" programmes being initiated in Europe, the US, China and other countries aimed at fostering competitive "green industries". Such investigations, it is suggested, would include the extent to which 
the rapidly growing collection of environmental industries commonly associated with the green economy can be seen as symptomatic of a deep-seated shift towards new modes of production that contribute to a more complete decoupling of economic growth from resource consumption, pollution and social deprivation, or are merely reproducing existing sustainability deficits as part of attenuated growth strategies.

In answering this question, our main focus is on conceptual aspects of the growth debate rather than detailed methodological and empirical issues. The discussion begins with a brief history of growth debates and the contribution of economic geography to these debates. We then examine the conceptual facets of post-growth philosophies before introducing relevant theoretical approaches and ways to operationalize them. Following this, examples are provided of issues surrounding the spatial facets of de-growth that could be addressed productively within economic geography. The article concludes by discussing the potential for original economic geography contributions to the understanding of the green economy and possible post-growth futures.

\section{Growth debates and economic geography}

Debates on the non-sustainability of economic systems based on standard growth principles (in both market and planned economies) have recurred in many countries since at least the Club of Rome Report on the limits to growth in the 1970s (Meadows et al.1972). Since then, events such as the Brundtland report (WCED 1987), the 1992 United Nations Rio Earth Summit, negotiations around the Kyoto Protocol in 1997, and longstanding debates on hunger, resource conflicts, and dwindling oil reserves have sparked discussions that have occupied a more prominent place in media and politics, albeit temporarily. Nevertheless, in-depth discussions on alternative development scenarios and economic models have remained limited for the most part to small groups of experts or non-government organizations (Lovelock 1979; von Weizsäcker et al. 1998; Latouche 2006; Worldwatch Institute 2012).

In scholarship, too, despite the work of prominent commentators such as Herman Daly, disciplines such as ecological economics have largely failed to influence mainstream economics and economic modelling (Daly 1996). Even though scholars criticizing the negative impacts of conventional growth paradigms (e.g. Ostrom 1990; Sen 1999; and
Stiglitz et al. 2009) have reached out to wider audiences, it is apparently only the more recent culmination of the hunger, climate and financial crisis (Jorberg 2010) that has persuaded liberal and conservative politicians alike to discuss the limits of the current model of capitalist market systems and the possibility of adjustments or more systemic changes in the orientation of economic planning.

Even though such debates have not yet discernibly infiltrated mainstream economic thinking and policy, the growth debate seems to be gaining some momentum in broader societal and political discourses. It is somewhat puzzling, therefore - particularly when one considers the vibrant debates on growth taking place in other branches of the social sciences (including other parts of geography) - that the majority of contemporary concepts and models in mainstream economic geography either remain within a traditional growth paradigm or, at least, do not critically assess its implications, even where research engages explicitly with concepts such as the green economy. Even though much research in environmental economic geography focuses on aspects of growth (Braun et al. 2003; Gibbs 2006; Bridge 2008; Hayter 2008; Soyez and Schulz 2008), it generally fails to address more fundamental issues related to the future of growth as a primary locus of economic activity.

However, scholars in adjacent subfields of human geography, not necessarily associated with the core of economic geographers, have tackled the growth issue more explicitly. These range from neoMarxist critiques of sustainable development over deeper reflexivity about human-nature relationships (Huber 2010; Swyngedouw 2010; Harvey 2012), critical analyses of carbon markets (e.g. Bailey et al. 2011) to the field of "diverse economies". Scholars in the latter tradition have made important contributions to exploring various "alternative" production, ownership, labour, exchange and consumption processes that operate distinctively from mainstream capitalism, including unpaid labour, local trading systems and cooperatives (Gibson-Graham 2008; Healy 2009). The proliferation of innovative economic practices under the umbrella of the green economy will doubtless create further opportunities for economic geographers to engage with the theoretical and practical dimensions of economic diversity.

Despite the contribution of diverse economy perspectives to unpacking the complexities and multiple motivations of economic activity, 
Gibson-Graham (2008, p. 615) maintains that one of its key goals is 'to understand the world in order to change it [by producing] a discourse of economic difference as a contribution to a politics of innovation' (emphasis added), even if this ambition has become less oriented towards structural critique and more concerned with examining the performative aspects of economic activity in order to identify, explore and create more imaginative and ethically negotiated economies. Our contention, nevertheless, remains that significant segments of the economic geography community continue to view capitalist economic orientations as a given and pay limited attention to alternative economies (Gibson-Graham and Roelvink 2009).

Additionally, diverse economies scholars have arguably not (yet) asked direct enough questions about the goals of alternative economies as part of their endeavours to explore the possibilities and barriers to modifying and subverting more neoliberal and capital-centric economic practices. How the performance of different economic forms is measured, how these complement and challenge mainstream wealth accumulation measures (particularly GDP), and the means through which other measures of societal well-being gain influence remain incompletely answered questions. Greater excavation of such questions forms a crucial component of any ambition to "change the world", not least because, despite the frailties of conceptual binaries between a dominant capitalism and inconsequential alternatives, the UN's support for the green economy is at least partly motivated by a desire to effect a paradigm shift from an economic system 'that allowed, and at times generated, [environmental, food and economic] crises to a system that proactively addresses and prevents them' (Ocampo 2011,p. 2). Put bluntly, the ontological reality of a dominant economic system cannot simply be wished away and a fundamental part of exploring economic transformations involves exploration of the transformative potential of alternative economic indicators.

Here again, intense debate has emerged on alternative indicators for monitoring individual wealth and the ecological and social dimensions of development that provide opportunities for economic geography research on diverse economies and GDP and growth as primary yardsticks of prosperity. The case for greater attention by economic geographers to indicators is further reinforced by the recognized weaknesses of GDP:
- Like many economic indicators, GDP refers only to quantitative measures and reveals little about the quality of growth (CEC 2009). For instance, public expenditures to compensate for health and environmental damages are factored into, and contribute to, wealth creation. Conversely, services that are not measurable in market terms (e.g. private care for children, the elderly and domestic work) are excluded, leading to inadequate representation of welfare situations in many households.

- Measuring regional economic growth provides conclusions about general developments but again GDP provides no indication about the distribution of well-being between population groups. Consequently, increasing social disparities and losses in real income among parts of the population are not captured by GDP.

- There is wide recognition of the limited link between increasing material prosperity and satisfaction, as identified by the Easterlin paradox (Easterlin 1974). Instead, many economies show that, beyond certain levels of prosperity, decoupling or even a negative correlation occurs between GDP growth and life satisfaction. This phenomenon was originally examined only in countries that underwent early industrialization, but has now been detected in numerous industrializing and developing countries using timeseries data (Easterlin et al. 2010). Easterlin's research has since laid the foundations for the growing resonance of happiness economics among international agencies such as the OECD.

Although alternatives to GDP have existed for decades (e.g. the United Nations' Human Development Index), the indicators debate has been re-energized by the OECD's Better Life Initiative report, which suggests 22 Headline Well-Being Indicators and provides comparable data for 34 states (OECD 2011). Further recent contributions include the Commission on the Measurement of Economic Performance and Social Progress Stiglitz-SenFitoussi Report commissioned by former French president Nicolas Sarkozy (Stiglitz et al. 2009). In most cases, however, these initiatives have developed supplementary indicators that do not seriously contest GDP as a basic benchmark for economic activity. In other words, growth is interlaced with sustainability, but growth remains the chief metric for judging economies.

Equally, limited evidence exists of concerted 
synthesis within the diverse economies literature of "success" indicators for non-market and other alternative economies. The emphasis instead centres on sketchier ideas of provisioning and meeting individual or group needs. For example, the Transition Network is organized around building community resilience and generalized benefits such as the use of local currencies to retain wealth and employment in communities (North 2010). The widely employed sustainable livelihoods framework, meanwhile, uses the natural, social, physical, financial and human assets held by individuals or communities as measures of their capacity to pursue livelihood strategies (Lindenberg 2002). For understandable reasons, the focus of many alternative economies is on improving the lot of individuals and nature but is uncommunicative about the role of growth (at aggregate or lower levels) within such processes. Gibson-Graham and Roelvink (2011) maintain that the task of economic alternatives research is to explore possibilities in order to facilitate ethical debates on more environmentally attuned and socially oriented economic practices. The future of growth, and the methods used to assess progress under the green economy, is a prime example of these ethical debates and an important focus for future explorations of economic diversity.

Despite these achievements and research strands, the fact remains that the majority of models, concepts and empirical studies discussed in the international core community of economic geography (see the programmes of the Global Conferences on Economic Geography in Singapore 2000, Beijing 2008 and Seoul 2012) place primary emphasis on traditional understandings of capitalist accumulation and growth paradigms.

\section{De-growth concepts and debates}

Before discussing conceptual debates on economic growth and de-growth in more detail, it is appropriate to specify and contextualize some key terms, in particular post-growth. Post-growth in the current discussion should not be taken to mean shrinkage (e.g. arising from demographic change) or recession (decreasing economic performance) which might produce windfall environmental benefits. Rather, we refer to a departure from dominant growth paradigms in the sense of Serge Latouche's décroissance (also "de-growth", see below); a rejection of the maxim that private and societal prosperity can only be ensured via continuous growth in materially and monetarily measurable economic performance - irrespective of negative externalities or the finite availability of resources and ecological sustainability. The formulation 'prosperity without growth', proposed in Tim Jackson's report to the UK Government (Jackson 2009), neatly captures the post-growth's orientation of a transition towards sustainable lifestyles and economic systems. Such formulations also place strong emphasis on distributive justice in growth and wealth, both in international and development policies and within national economies (also see debates on pro-poor growth; Rippin 2012).

In addition to previously mentioned debates on the limits to growth and scientific research on specific ecological issues (biodiversity, desertification, water) and climate change, debates about the future of growth have been significantly informed by ecological economics (Daly 1996; Costanza et al. 1997). Ecological economists have sought to dissociate themselves from neoclassical economics by not following the latter's categorical separation between human and natural capital and instead regard economy as a subsystem of the global ecological system. Ecological economics thus presumes a factual finiteness of material and energy availability and calls for economic forms that slow down processes of entropy. Crucially, a steady-state economy (an economic system in which energy and material consumption are in balance with recycling and energy recovery) is considered to be genuinely achievable through an "efficiency revolution" involving the organizational and technological optimization of energy and material uses in production and consumption. For instance, the Factor 4 model promises a doubling of prosperity with a halving of resource use (von Weizsäcker et al. 1998) and has since become emblematic of strategies aimed at overcoming negative growth impacts through step increases in energy and resource efficiency. As a scheme (since expanded to Factor 5 and Factor 10) that suggests further improvements in wealth and living standards are possible if resource consumption is reduced accordingly, the approach has gained momentum outside academia and contributed to raising the awareness of political decision-makers to potentially viable alternative growth paradigms.

Although such concepts have been developed further (von Weizsäcker et al. 2009), the possibility of decoupling of economic performance from resource use via process optimization and technological innovation are questionable (see Paech 2010 for a critique of the "decoupling myth"). Despite 
multiple progressive efficiency increases, decoupling generally falls down due to rebound effects, where savings in the energy balance of products achieved through improved production methods are lower than the additional energy needed to design, erect and run new production units. Similarly, consumer durables may become more energy efficient, but when the replacement of the preceding appliance occurs too soon, the residual "embodied energy" in the new appliance still has a negative influence on overall energy balances. Despite its methodological progress and growing number of advocates, Life Cycle Assessment has not been systematically established as a decision support tool. Finally, one must consider consumer behaviour, particularly tendencies for increased consumption in response to acquiring new, lower-impact and lower operating-cost appliances and goods (Rothenberg 2007; Sorrell 2007; Paech 2010). As such, development strategies that embrace green growth are in danger of undermining steady-state principles before one starts to consider wider trends such as demographic growth and the expansion of the global middle class.

These latter considerations generated early criticism of the principle of the steady-state economy, particularly by Herman Daly's mentor, Nicholas Georgescu-Roegen. Operating from a bio-economic perspective, Georgescu-Roegen $(1971,1995)$ argued that only décroissance, or de-growth, could ensure the long-term survival of humanity and that a steady state was utopian under existing physical, demographic and cultural conditions (see Kerschner 2010). Serge Latouche has since been highly influential in further developing the décroissance principle and promoting the rejection of growth-oriented production and consumption, a stance that resonated strongly with the Italian, Spanish and French sustainability movements (Latouche 2006, 2010). Georgescu-Roegen and Latouche's work has, however, always included developmental and globalpolitical dimensions that view resource exploitation in relation to environmental justice and social equity rather than just through ecological lenses. Indeed, Latouche (2010) has argued that the global South above all is capable of realizing alternatives to Western market maxims, and that the global North could create manoeuvring space for Southern development by reducing its claim on resources.

Latouche and the décroissance community have also dissociated themselves from models of ecological modernization that consider a transition to sustainable economies to be possible within present market principles. Like the Factor 4 approach, ecological modernization has been criticized for its optimism about the viability of continuous - if modified - growth. Critical assessments of mainstream climate policies and carbon markets (Redclift 2009; Bailey et al. 2011; Böhm et al. 2012) suggest systemic shortcomings in the reformed growth model proposed by ecological modernization. Kindred concepts such as green growth, smart growth or the ambiguous term qualitative growth (increasing the profitability of enterprises without increased use of resources) are also criticized for taking insufficient account of systemic problems in underlying models of capital accumulation and wealth (Bina 2013). As Swyngedouw (2010, p. 222) puts it:

An extraordinary techno-managerial apparatus is underway, ranging from new eco-technologies of a variety of kinds to unruly complex managerial and institutional configurations, with a view to producing a socio-ecological fix to make sure nothing really changes.

David Harvey (2012, p. 86) provides a similar interpretation:

The environmental commons are no less threatened, while the proposed answers (such as carbon trading and new environmental technologies) merely propose that we seek to exit the impasse using the same tools of capital accumulation and speculative market exchange that got us into the difficulties in the first place.

Although general denial of the environmental benefits of eco-technologies would be misplaced, the crux of this critique rightfully questions such greening concepts' adherence to the quantitative growth of economic systems and for propagating post-political arrangements in which open-minded debates on potential alternative economic and socioenvironmental futures are replaced with imposed or creeping consensus and managerialist approaches to how humanity deals with interfaces between economic and environmental systems (Swyngedouw 2010). In contrast, décroissance posits a more holistic view of the socio-cultural dimensions of growth that includes consideration of values and norms as well as consumption and production patterns, making décroissance an ecological-democratic project. Here, efficiency concepts can be contrasted with those of sufficiency, illustrated by Latouche's "five 
Rs" (e.g. réévaluer, réduire, recycler, réutiliser, restructurer, redistribuer, i.e. revalue, reduce, recycle, reuse, restructure and redistribute). This again illustrates the emphasis placed on how material consumption can be reduced without impairing personal satisfaction and well-being, while at the same time contributing to improved living conditions among economically underprivileged populations and regions via a fairer distribution of resources. In this context, discussions over material property and the commodification or non-commodification of goods and services acquires particular importance.

The sufficiency principle does not fundamentally question growth per se but focuses attention on which activities, product groups, services and forms of consumption are likely to generate growth effects, and which segments of the population should benefit to uphold distributive justice. In contrast with the efficiency hypothesis, it is not assumed that adjustments should occur exclusively according to market principles, as is partly postulated by ecological modernization. Instead, sufficiency seeks more profound changes in consumption preferences, lifestyles and political priorities (e.g. research policy, public procurement, fiscal policy and incentive tools).

It is important to stress that the sufficiency approach should not be interpreted as an attempt to generalize idealistic lifestyles of individual selfrestraint (e.g. dietary, consumption or mobility behaviour) or as top-down, state-imposed limitations. Rather, it proffers an alternative paradigmatic model of future social and economic decision-making for assessing the long-term effects of investments and governance mechanisms on resource consumption and other negative growth externalities and social distribution. While analogies exist between the sufficiency concept and some principles of sustainable development, sufficiency may prove less problematic to operationalize in some respects (assuming some agreement is possible on the definition and calibration of "sufficiency") and may offer fewer opportunities for interpretations that skew the concept towards econo-centric concerns (Redclift 2009). However, Walker and Shove's (2007) warnings about the ambivalent and contested nature of sustainability transitions apply equally to attempts to put ideas of sufficiency into practice. Latouchian notions of post-growth nevertheless signify a conscious departure from traditional, materially and monetarily conceptualized growth towards an orientation that emphasizes development strategies based on long-term viability and global distributive justice. The latter goes beyond the mere redistribution of monetary wealth but, instead, comprises a more complex conceptualization of poverty eradication that encompasses not only the obviously material but also equal opportunities, health, quality of life, environment and political participation.

\section{Spatial facets of post-growth transitions}

Economic geography has a major opportunity to contribute towards understanding the space-related causes, processes and effects of current and potential future economic and social changes associated with the green economy and alternative conceptualizations of growth. Four areas of analysis have particular potential for economic geography to develop innovative approaches and insights:

1. new spatial patterns of production and consumption induced by rising energy and resource costs;

2. regional and local "transition" strategies for moving towards decentralized sufficiency, the decommercialization of goods and services, and social enterprises and "solidarity economies" that seek to create synergies between local private and public actors to offer new services, workplace opportunities and proximity services (Moulaert and Ailenei 2005);

3 . trends in the adoption of more environmental friendly and resource efficient modes of designing, producing and using manufactured goods, including trends towards shared-use concepts and "servicizing" - the life-cycle extension of manufactured products through maintenance and repair services as a way of creating new business opportunities for firms (Rothenberg 2007); and

4. the development of ethical or sustainable investment products by the financial sector, including the financialization of renewable energy and development policies (e.g. microfinance investments) in the global South that are often overlooked in the "greening" literature.

These four realms are now discussed briefly to illustrate the diversity of opportunities available, rather than to provide in-depth analysis of specific themes. The list is also far from comprehensive and should not be viewed as a research agenda. It merely provides preliminary reflections about aspects of possible transitions to post- or modified-growth economies challenging economic geography in the short term. 
Economic geographies of rising energy and resource costs

Changes in energy systems (Energiewende, low carbon transition) are unlikely to be the sole area of interest for economic geographers stemming from concerns about climate change and future fossilfuel availability. Rising transportation costs are already beginning to impact on global freight traffic and, if recent trends continue, the potential exists for appreciable changes in freight and cargo flows and international trade relations (North 2010; Bridge etal. 2013). As such, transportation costs (formerly a key location factor in neo-classical models) may acquire renewed relevance for economic geographers. Changed transport conditions may also impact on agricultural production in industrialized nations if rising import prices and changing consumer preferences encourage a trend towards the re-regionalization of production and marketing (Fedrowitz and Albers 2008). In addition, many cities are seeing a revalorization of derelict areas for food production for personal consumption, alongside a renaissance in allotments. While in the industrialized nations, urban farming is a newly popularized phenomenon, they are an established form of urban subsistence in many developing countries (see Farmar-Bowers et al. 2013). More generally, changing lifestyles, attitudes and value systems might be influenced by resource discourses; thus, the 'sustainability of everyday life' (Shove and Walker 2010) and attempts to govern transitions without prescribing citizen choices deserve both scientific and political interest.

In the energy sphere, strategies to promote renewable energies often coincide with concepts of decentralized energy production and supply (Wolsink 2011). Private or communal micro-generation (photovoltaics, biomass, wind energy) are gaining momentum alongside debates on the re-regionalization of supply grids and ideas of energy self-sufficient communities. Initiatives such as the energy provider Schönau in the Black Forest serve as a potential model for larger initiatives, such as the recent referendum in Hamburg calling for a recommunalization of energy supply and the reacquisition of the power grid from the Swedish company Vattenfall (though a similar referendum in Berlin recently failed). There is some evidence that the communal level is playing a more prominent role in aspects of energy policy and climate protection (Bulkeley et al.2011), though government measures to stimulate localized energy production, such as the
UK's feed-in-tariff scheme for renewable energy installations of less than 5 megawatts, are also producing interesting shifts in the geographies and politics of energy production. However, none of these systems deal with the quantitative aspects of demandside issues.

\section{Regional transition approaches}

Economic geographers have been slow compared with other branches of geography to engage with the various initiatives promoting economic relocalization that have emerged under the banner of the Transition Towns Network or the Cittàslow network established in 1999 in Italy. Similarly, scope remains for greater economic geography contributions to debates among environmental, political and critical geographers on cities as arenas for addressing climate change (Bulkeley et al. 2011). Transition Towns and city-level initiatives on energy and climate change provide interesting contrasts for economic geographers working on regional innovation systems, both in respect of their orientations towards growth vis-à-vis alternative conceptualizations of well-being and the processes by which greener economies are pursued. Whereas Transition Towns see "the end of growth" as inevitable (Bailey et al. 2010), addressing energy and climate issues is identified by many city-regions as a means of enhancing competitiveness in the global economy (Gibbs and O’Neill 2014). Similarly, whereas urban climatechange responses are often enacted primarily in terms of 'processes of change ... driven primarily by institutional and political processes' (Bulkeley etal. 2011, p. 3), Transition Towns offer more experimental and community-led approaches to mediating low-carbon transitions at the local and regional levels (Hodson and Marvin 2012). Such comparisons between transitional orientations and strategies may build productively on geographical innovation research by Cooke (2008) and others on "transition regions", which examines how economic areas seek to create regional platforms for mobilizing technological, organizational and entrepreneurial innovation in order to distinguish themselves from other regions as nodes of sustainable production and consumption. Also noteworthy in this context is related research on eco-technology and greeneconomy clusters (Cooke 2008, 2010; McCauley and Stephens 2012).

Another feature of the Transition Towns concept worthy of further investigation by economic 
geographers is the initiation of various de-commercialized economic exchange systems. Until now often regarded by economic geographers as niche phenomena not especially worthy of investigation, parallel economy initiatives such as online and local swapping sites and local currencies may acquire greater prominence in times of austerity and as part of the broader contours of the cultural green economy. An interesting feature of such initiatives is again their emphasis on local solidarity economic models and increasingly market-independent (and non-growth-oriented) orientations. Examples of such initiatives meriting greater analysis from an economic geography perspective include the Totnes Pound (UK, introduced in 2007) and similar initiatives in other towns and municipalities (e.g. the Chiemgauer in Southern Bavaria/Germany, introduced in 2003, and the Beki in Beckerich/ Luxembourg, introduced in 2013). Such new local economies and their impact on "conventional" retail, trades and other consumer services have so far received little attention within economic geography, despite considerable interest from other parts of the discipline (North 2005). However, their potential proliferation as a reaction to top-down, growth-centred approaches to the green economy suggests that greater attention is needed to how previously marginal forms of economic activity are influencing the emerging shape of the green economy.

\section{New modes of production, consumption and financialization}

Alongside changes in conventional production methods and local green economy "experiments", scope remains for deeper investigations by economic geographers into linkages between resource intensity and product design, durability, renewal and maintenance. Although accelerated product or technology obsolescence cycles and new acquisition instead of repair have become standard devices for sustaining growth in sectors such as communications and information technology, there are indications that attitudes are changing among some corporations and sectors. Alternatives to achieving profitability through growth in sales include the adoption of life-cycle management approaches and activities providing dematerialized solutions to consumer preferences through the provision of service and repair services (Mont 2002). In particular, the bundling of production and services into Industrial Product Service Systems provides one avenue for adding value through maintenance and repair aimed at extending product life cycles and producing resource-conserving effects that moderate conventional growth strategies (Manzini and Vezzoli 2002).

From the consumer perspective, linkages between the sufficiency concept and reducing material consumption span questions of property rights, the lifespan and service life of consumer goods, means of production, and real estate. There are signs that it is not only Transition Towns that are exploring new avenues in communal use and investment in more resource-efficient products and technologies (Ostrom 1990; Helfrich and Heinrich-Böll-Stiftung 2012). Examples include previously mentioned cooperative organizations engaged in renewable energies or operating power grids, the communal use of consumer goods such as cars and bicycles, and joint ventures to develop private real-estate projects in expensive urban locations. Such ventures involve different motivations and processes, and rarely comprise commons in the original sense. Rather, they create club goods (partly highly exclusive, e.g. communal building projects) or impure public goods, but what they share is the implicit or explicit rejection of the privatization, enclosure and commodification of common property that has pervaded neoliberal approaches to economic management (Bakker 2010). Through such initiatives, alternatives to purely market-oriented or state-planned economic management are emerging based on principles of long-term viability (economic sustainability), resource efficiency (ecological sustainability), benefit sharing over profit maximization, and the inclusion of financially weaker groups (social sustainability).

The new commons movement shows similarities with a range of activities falling under the banner of collaborative and sharing economies, or "shareconomy" as organizers of the 2013 CeBIT trade fair in Hanover, Germany, described it (CeBIT 2013). Similarly, non-profit organizations, such as France-based ouishare.net, bring together "old" forms of collaboration such as car-pooling, couch surfing, and local exchange trading systems with newer forms of creative knowledge and resource sharing (e.g. crowd sourcing for business innovations, open access to knowledge as source for innovation and peer-to-peer finance) (P2P Foundation 2012). These and other IT-based modes of co-production and co-consumption will presumably gain momentum as new market opportunities are identified for knowledge exchange around green-economy topics that may, in turn, contribute to further 
economic dematerialization and improvements in resource efficiency within a non-ownership/shareduse approach.

However, the common's approach is also criticized for being susceptible to manipulation. As Harvey (2012, p. 78) notes: 'The better the common qualities a social group creates, the more likely it is to be raided and appropriated by private profitmaximizing interests'. Moves by transnational corporation in the IT and manufacturing sectors (e.g. IBM, Fiat) to explore crowd sourcing as a market opportunity provide an early indication of the ambiguity of the concept. Either way, greater attempts by economic geographers to explore these new forms of production, consumption and resource valuation and compare the processes through which such practices are emerging with more neoliberal approaches to environmental governance might allow scholars within and beyond economic geography to develop a more comprehensive account of how social and economic systems are responding to the green economy and de-growth agendas.

In addition to new product and service concepts and new geographies of production organization, there are also indications of more systemic changes in the finance industry that touch on green-economy and post-growth debates. These include the crisisrelated (partial) nationalization of banking corporations as well as changing investment behaviour among private and institutional investors (e.g. sustainable funds, ethical investment) and the spread in popularity of alternative financing tools, such as the microfinance industry (Walther et al.2011). The Sharia-compatible investment policy collectively known as Islamic banking (Ernst \& Young 2010) also provides connections to post-growth concepts by virtue of their interest-free features - though this industry generally relies on a traditional growth paradigm and other strategies of earning profit.

Not all the aforementioned examples have the same scope or relevance to the green economy, and certainly not all of them contribute obviously to changes in growth preferences and resource consumption patterns. At first glance, energy issues and related changes in industrial production patterns seem to be more conventional responses to resource scarcity rather than deliberate attempts to limit resource-based growth, though some underlying policy strategies and funding programmes like the UK's low carbon transition programme and the German Energiewende rest explicitly on strong sustainability if not post-growth aspirations.
Other initiatives, meanwhile, are criticized for producing ambivalent effects. The microfinance industry, for instance, has been described as the 'subprime of all subprime forms of lending' (Harvey 2012,p. 86), and is increasingly suspected of merely extracting wealth from the poor following the entry of larger financial corporations into this market. Ali (2014) further illustrates how discriminatory and poverty-reinforcing microcredit practices are far from restricted to major corporate players in his investigation of the subordination of female borrowers in Bangladesh by NGOs and male relatives. Others like the new urban commons or the joint building ventures have yet to gain sufficient momentum to tell whether they will remain as niche experiments or become part of a more sustained trend towards the dematerialization and socialization of property and capital. However, many of the developments discussed seem to be enjoying broadening acceptance among a variety of consumer groups and, thus, may have the potential to produce greater impacts on organizational patterns, spatial flows and capital accumulation strategies. They often involve new forms of organization (e.g. cooperatives) and many not only follow profit-oriented objectives but also use community-based marketing, low-cost action and participatory governance strategies to overcome social and market barriers (Viardot 2013). As such, they deserve thorough analytical monitoring that both utilizes and challenges the skills and perspectives of hitherto dominant approaches within economic geography.

\section{Concluding discussion}

The future of economic growth is arguably one of the fundamental questions within contemporary debates on the transition to a green economy. Thus far, the predominant line of thinking by the UN and national governments appears to prioritize more socially and ecologically balanced, but still essentially growth-centred, models that Matthews (2011) describes as promoting powerful vested interests, short termism and financialization. Having explored critiques of neoliberal discourses on "smart-growth" economics articulated by advocates of post-growth and de-growth perspectives and some of the spatial facets of post-growth transitions, the final part of this article examines future potential contributions by economic geography to more systematic and imaginative research on post-growth concepts and broader ideas of economic and societal transitions. 
In keeping with the aim of the themed issue to initiate deeper discussion among geographers about the nature and implications of the green economy, we begin by synthesizing the core ideas emerging from this and other articles in the themed issue and reflect on their consequences for future research within economic geography and other branches of geography concerned with human-environment relationships and sustainable development.

The first major theme concerns the relational geographies involved in the forging and contestation of the green economy concept. Georgeson et al. (2014) explore the importance of social relations to the identity and operation of cleantech investment networks, a pivotal component of the green economy's financial domain. By examining how cleantech investors define the sector, the macro- and microlevel drivers of cleantech investment, and how the formation of cleantech networks generate trust and information sharing, they exemplify how cleantech investment has burgeoned around traditional markets concerns about market-making and financial return rather than on the basis of the sector's potential environmental benefits. This article, meanwhile, draws attention to the multitude of arenas in which neoliberal constructions of the green economy are being contested by actors seeking to promote alternative economic orientations and motivations.

The second major theme concerns the value of geographical perspectives in helping to understand the mechanisms and processes through which green economy ideas take practical shape. Gibbs and O'Neill (2014) argue that incorporating ideas of scale and spatial perspectives can provide greater insight into why and how green economy transitions emerge and flourish in some places but not others than research that does not consider the geographical aspects of socio-technical transitions (also Davies 2013). Using the example of Boston, USA, they illustrate how the region's green economy identity has developed not from a tabula rasa, but out of existing strengths and networks and a longstanding commitment to environmental leadership by the city government and other major local actors. Relational green economy geographies of a different sort underpin Barr's (2014) discussion of the consumption behaviour in the developing green economy. Barr argues that the current tendency for environmental social science and policy to focus on individuals as a major source of change has stifled debate on how personal behaviours develop in association with, and are influenced by, wider social milieus and economic contexts. Barr thus emphasizes the need for greater engagement by environmental social scientists with the relational and social dimensions of green consumption practices and with the political drivers and governance frameworks that have supported individualist approaches for promoting societal change.

A final major theme concerns political power relations within the green economy. Brown et al. (2014) argue that current conceptualizations of the green economy have done little to challenge uneven political and economic relations between the global North and South or to meet the basic needs of the world's poor. Based on analyses of the Mesoamerican Biological Corridor and initiatives in Brazil, they contend that green growth strategies have been dominated by technological fixes and the reproduction of Northern strategic economic and ideological interests. Although they stress that it is too early to judge how far and how the green economy might become an effective vehicle for mitigating both poverty and the effects of environmental change, they maintain that investigations into the role of the green economy in addressing such problems must incorporate critical understandings of the complex socio-economic processes through which poverty and inequality are produced and reproduced in different geographical settings rather than accepting the green economy as a bolt-on to existing structures, patterns and processes of globalizing capitalism. Knox-Hayes and Hayes' (2014) examination of emissions markets makes two further crucial points about power relations in the economic logics to environmental problems: the general receptiveness of polities to "technocratic" green economy solutions, like emissions markets, that are heavily grounded in universalistic economic logics and assumptions; and the impact of cultural and political differences in shaping how such are approaches are interpreted, practised and contested.

The relevance and spatial dimensions of these topics suggest that the green economy provides a fertile arena for contributions by economic geographers to debates on economic transitions and post-growth paradigms. Although some strands of economic geography work on the green economy might be reproached for a lack of systematic engagement with alternative growth paradigms and/or their implications for current economic orientations and systems, several of the topics also indicate that established approaches can be applied to post-growth transitions. In particular, economic geography's 
longstanding experience with regional structural change and regional innovation systems, the spatiality of value chains and production networks, and the context conditions shaping economic activities and the co-evolution of politics, society and economics provides promising foundations for further economic geography research on the market, institutional and spatial dynamics of both smart-growth and de-growth economies. Concepts of evolutionary economic geography, geographical innovation research and network and cluster research could be developed further, as could more recent approaches of practice research and financial geography (Patchell and Hayter 2013).

In more general terms, following GibsonGraham's (2008) earlier arguments, greater attention is needed to empirical research on the relational geographies affecting the green economy's goals, sites of practices, including further engagement with co-evolutionary perspectives on societal changes and economic transitions. Greater use of sociotechnical transitions approaches utilized extensively by other social sciences may provide particularly interesting opportunities for combining more traditional economic geography approaches with deeper analysis of interplays and the co-evolution of societal, technological and governance innovations (for overviews, see Elzen etal. 2004; Schot and Geels 2008; Truffer and Coenen 2012). As Gibbs and O'Neill (2014) argue, socio-technical transitions perspectives have made important advances in elucidating the processes through which innovations develop within niche environments (in some cases) to challenge established socio-technical regimes. However, they have rarely included explicit consideration of the spatialities of these processes (Truffer 2008). Additionally, only a small portion of sociotechnical transitions research has moved beyond relatively general analysis of the "level-shifting" processes through which innovation niches challenge regimes to engage with the detailed economics and economic geographies affecting the ability of transition experiments to traverse this next level of innovation diffusion (see, e.g. Fouquet 2010).

Aside from their insufficient conceptualization of space (Truffer and Coenen 2012; Bridge etal. 2013), transition studies have been criticized for focusing heavily on technological invention and comparative neglect of organizational, procedural and governance innovations (Affolderbach and Schulz 2014; though see Vo $\beta 2007$ on the innovation journey of emissions trading and Seyfang and Longhurst
2013 on grassroots innovation). The latter critique also applies partly to evolutionary economic geography, and was one reason for Patchell and Hayter's (2013) call for integration between environmental economic geography (EEG1) and evolutionary economic geography (EEG2), based on the idea of $\mathrm{EEG}^{2}$, as a means of ensuring that economic geographic perspectives are fully incorporated in debates over the co-evolution of economy and environment. They argue both conceptually and normatively that 'incorporating the environment, and recognizing economic geography's growing interests in this regard ..., could be as important a contribution to understanding economic development as EEG2's claim to compensate for neoclassical economics' focus on equilibrium states and failure to deal with institutional change' (Patchell and Hayter 2013 , p. 111). Used in conjunction with well established institutional perspectives and multi-level approaches, economic geography has strong potential to make original contributions to critical debates on the green economy and emerging post-growth practices.

Such conceptual advancements in economic geography linked with interests in sustainability issues may also help to prevent research on the green economy becoming too case-study oriented and lacking in theoretical or empirical coherence. A number of options exist here, including analysis of keynote themes, such as green economy identities, practices, and power relations noted above (e.g. scholarly work accompanying the German Energiewende; Klagge and Brocke 2012). Another might involve structuring of the green economy into functional domains. Bailey and Caprotti (2014, p. 1800) conceptualize four such domains:

1. a financial domain incorporating the range of actors, such as venture capital firms and financial institutions, involved in green economy investment and business activity;

2. an institutional domain encompassing the various institutional actors seeking simultaneously to govern and to establish a place in the green economy;

3. a regulatory domain dealing with the various components of rule-setting and standard-setting for green economy activities; and

4. a cultural domain covering the wide array of new "green" modes and geographies of production and consumption taking shape within the green economy. 
In a similar vein, Bridge et al. (2013) make the case for examining energy transition as a geographical process and identify six spatial constructs to help structure assessments of the geographical implications of transitions towards low carbon energy: location, landscape, territoriality, spatial differentiation, scaling, and spatial embeddedness. They further argue that attention to the spatialities of transitions to a low-carbon economy can aid understandings of what living in a low-carbon economy will be like while foregrounding questions about, among other things, spatial difference and the co-existence of multiple transition pathways and possibilities.

A more explicit focus on the functional and spatial aspects of the green economy and their interrelationships may provide useful devices for configuring analysis of the multitude of relational geographies involved in the making, operation and governance of the green economy that avoids portraying them either as some sort of monolith (Gibson-Graham 2008) or as empirically and analytically disjointed phenomena. Whatever the conceptual vantage point taken, analysis of the ways in which different spaces and domains within the green economy reproduce, reshape, or revolutionize contemporary conceptualizations of economic growth forms an important part of such investigations.

This article could only explore a few threads of the host of conceptual debates relevant to economic geography research on green growth and postgrowth. Even so, it is clear that there is no shortage of perspectives or research themes. Although spatial research has shown increasing interest in green businesses, green innovation and local and regional sustainability strategies, more fundamental questions about the underlying mechanisms and general framework conditions of prevailing economic systems have remained more neglected and sustained dialogue between economic geographers and postgrowth scholars in the décroissance community and elsewhere has yet to emerge (for a rare example, see Zademach and Hillebrand 2013).

Despite some of the potential interfaces noted in this article, a more critical view on "reformed growth", informed by post-growth thinking, seems timely as momentum begins to accumulate behind the green economy, in order to monitor the impacts of conventional growth logics and the consequences of potential societal and other trends towards a more décroissance perspective. Here, a global perspective, taking into account the contexts and framework conditions influencing green economy developments in the global North and South (as well as their interconnectedness and reciprocal impacts), offers further opportunities to tackle challenging societal questions using and - if necessary - adapting established geographical concepts.

Although some proponents of ecological modernization and eco-efficiency approaches might argue otherwise, the green economy encompasses not just technological and organizational challenges but also poses more holistic societal challenges regarding the future orientation of economies. Transition studies can, when applied beyond particular industries or technologies to local or regional contexts, provide interesting opportunities for economic geographers to link existing concepts and methodologies (e.g. regarding localized innovation systems, regional transformations, and institutional change) with analysis of reformed and post-growth transitions and their spatial dimensions. As the various examples discussed indicate, emerging civil-society movements such as Transition Towns are arguably symptomatic of broader questioning of current economic emphases and practices spanning other sectors of production and consumption. If these continue to proliferate, they may begin to exert greater influence on energy policy, transportation, housing, natural resource management, private consumption, political participation and knowledge creation. Even though such processes are often created without firm agendas, they contribute towards more general scrutiny of established economic systems and negotiations over possible new societal orientations. Compared with government or business-driven attempts to green current market logics, the concept of post-growth transitions arguably has the potential to draw in a broader range of stakeholder perspectives, particularly those of individual consumers and civil society groups, as part of re-democratized debates on what the green economy means and might come to mean. Given the highly fluid nature of the green economy, the sectoral vantage points frequently applied in economic geography need to pay more attention to the complex co-evolution of social institutions, technologies and production systems. Independent of the scalar focus, the spatial characteristics of such change processes represents a major challenge for economic geography's reputation as an integrative discipline tackling pertinent questions on sustainability imperatives. 


\section{Acknowledgements}

The authors would like to thank Federico Caprotti, the three anonymous reviewers and the editors of this journal for their very helpful suggestions and their guidance during the publication process. All remaining errors, omissions and contentious arguments are solely the responsibility of the authors.

\section{Christian Schulz \\ Institute of Geography and Spatial Planning \\ IPSE Research Unit \\ University of Luxembourg \\ Route de Diekirch \\ L-7220 Walferdange \\ Luxembourg \\ Email: christian.schulz@uni.lu}

\section{Ian Bailey \\ School of Geography, Earth and Environmental Sciences \\ Plymouth University \\ Drake Circus \\ Plymouth PLA 8AA \\ United Kingdom \\ Email: ian.bailey@plymouth.ac.uk}

\section{References}

AFFOLDERBACH, J. and SCHULZ, C. (2014): 'Mobile transitions? Green building innovations in urban contexts', paper presented at the Geography of Innovation Conference, Utrecht, 23-25 January.

ALI, H. M. A. (2014): 'Microcredit and power: examining how and why women encounter domination in Bangladesh', Development in Practice 24 (3): 327-338.

BAILEY, I. and CAPROTTI, F. (2014): 'The green economy: functional domains and theoretical directions of enquiry', Environment and Planning A 46 (8): 1797-1813.

BAILEY,I.,GOULDSON,A. and NEWELL,P.(2011): 'Ecological modernisation and the governance of carbon: a critical analysis', Antipode 43 (3): 682-703.

BAILEY, I., HOPKINS, R. and WILSON, G. (2010): 'Some things old, some things new: the spatial representations and politics of change of the peak oil relocalisation movement', Geoforum 41 (4): 595-605.

BAKKER, K. (2010): 'The limits of "neoliberal natures": debating green neoliberalism', Progress in Human Geography 34 (6): 715-735.

BARR, S. (2014): 'Practicing the cultural green economy: where now for environmental social science?', Geografiska Annaler: Series B, Human Geography 96 (3): 231-243.

BINA, O. (2013): 'The green economy and sustainable development: an uneasy balance?', Environment and Planning C: Government and Policy 31 (6): 1023-1047.

BÖHM, S., MISOCZKY, M. C. and MOOG, S. (2012): 'Greening capitalism? A Marxist critique of carbon markets', Organization Studies 33 (11): 1617-1638.

BRAUN, B., SCHULZ, C. and SOYEZ, D. (2003): 'Konzepte und Leitthemen einer ökologischen Modernisierung der Wirtschaftsgeographie', Zeitschrift für Wirtschaftsgeographie 47 (3-4): 231-248.

BRIDGE, G. (2008): 'Environmental economic geography: a sympathetic critique', Geoforum 39 (1): 76-81.

BRIDGE, G., BOUZAROVSKI, S., BRADSHAW, M. and EYRE, N. (2013): 'Geographies of energy transition: space, place and the low-carbon economy', Energy Policy 53: 331-340.

BROWN, E., CLOKE, J., GENT, D., JOHNSON, P. H. and HILL, C. (2014): 'Green growth or ecological commodification: debating the green economy in the global South', Geografiska Annaler: Series B, Human Geography 96 (3): 245-259.

BULKELEY, H., CASTÁN BROTO, V., HODSON, M. and MARVIN, S. (eds) (2011): Cities and Low Carbon Transitions. Routledge, London.

CAPROTTI, F. (2012): 'The cultural economy of cleantech: environmental discourse and the emergence of a new technology sector', Transactions of the Institute of British Geographers NS 37 (3): 370-385.

CEBIT (2013): 'CeBIT 2013 keynote theme: shareconomy covers all facets of digital living', CeBIT, Deutsche Messe, Hanover [online]. URL http://mm.cebit.de/en/about-the-trade-show/ news-trends/review-cebit-2013/keynote-theme-shareconomy [accessed 12 March 2013].

CEC (2009): 'GDP and beyond: measuring progress in a changing world'. Communication from the Commission to the Council and the European Parliament COM (2009) 433 final, Commission of the European Communities, Brussels, 20 August.

COOKE, P. (2008): 'Regional innovation systems, clean technology \& Jacobian cluster-platform policies', Regional Science Policy and Practice 1 (1): 23-45.

COOKE, P. (2010): 'Regional innovation systems: development opportunities from the "green turn"", Technology Analysis and Strategic Management 22 (7): 831-844.

COSTANZA,R.,CUMBERLAND,J.,DALY,H.E.,GOODLAND, R. and NORGAARD, R. (1997): An Introduction to Ecological Economics. St Lucie Press, Boca Raton, FL.

DALY, H. E. (1996): Beyond Growth: The Economics of Sustainable Development. Beacon Press, Boston, MA.

DAVIES, A. R. (2013): 'Cleantech clusters: transformational assemblages for a just, green economy or just business as usual?', Global Environmental Change 23 (5): 1285-1295.

DAVIES, A. R. and MULLIN, S. J. (2011): 'Greening the economy: interrogating sustainability innovations beyond the mainstream', Journal of Economic Geography 11 (5): 793-816.

EASTERLIN, R. A. (1974): 'Does economic growth improve the human lot?', in DAVID, P. A. and REDER, M. V. (eds): Nations and Households in Economic Growth: Essays in Honor of Moses Abramovitz. Academic Press, New York, pp. 89-125.

EASTERLIN, R. A., McVEY, L. A., SWITEK, M., SAWANGFA, O. and SMITH ZWEIG, J. (2010): 'The happiness-income paradox revisited', Proceedings of the National Academy of Sciences 107 (52): 22463-22468.

ELZEN, B., GEELS, F. W. and GREEN, K. (2004): System Innovation and the Transition to Sustainability: Theory, Evidence and Policy. Edward Elgar, Cheltenham.

ERNST \& YOUNG (2010): The Islamic Funds and Investments Report. Post crisis: waking up to an investor-driven world. Ernst \& Young, Dubai.

FARMAR-BOWERS, Q., HIGGINS, V. and MILLAR, J. (eds) (2013): Food Security in Australia: Challenges and Prospects for the Future. Springer, New York.

FEDROWITZ, M. and ALBERS, L. (eds) (2008): Nahrungsmittel und Raumplanung. Dortmunder Beiträge zur Raumplanung 
$\mathrm{P} / 29$, Institut für Raumplanung, Technische Universität Dortmund, Dortmund.

FOUQUET, R. (2010): 'The slow search for solutions: lessons from historical energy transitions by sector and service', Energy Policy 38 (11): 6586-6596.

GEORGESCU-ROEGEN, N. (1971): The Entropy Law and the Economic Process. Harvard University Press, Cambridge, MA.

GEORGESCU-ROEGEN, N. (1995): La décroissance . Entropie Écologie-Économie. 2nd edn. Éditions Sang de la terre, Paris.

GEORGESON, L., CAPROTTI, F. and BAILEY, I. (2014): “'It's all a question of business": investment identities, networks and decision-making in the cleantech economy', Geografiska Annaler: Series B, Human Geography 96 (3): 217-229.

GIBBS, D. (2006): 'Prospects for an environmental economic geography: linking ecological modernization and regulationist approaches', Economic Geography 82 (2): 193-215.

GIBBS, D. and O'NEILL, K. (2014): 'The green economy, sustainability transitions and transition regions: a case study of Boston', Geografiska Annaler: Series B, Human Geography 96 (3): 201-216.

GIBSON-GRAHAM, J. K. (2008): 'Diverse economies: performative practices for "other worlds", Progress in Human Geography 32 (5): 613-632.

GIBSON-GRAHAM, J. K. and ROELVINK, G. (2009): 'An economic ethics for the Anthropocene', Antipode 41 (S1): 320-346.

GIBSON-GRAHAM, J. K. and ROELVINK, G. (2011): 'The nitty gritty of creating alternative economies', Social Alternatives 30 (1): 29-33.

HARVEY, D. (2012): Rebel Cities: from the Right to the City to the Urban Revolution. Verso, Brooklyn, NY.

HAYTER, R. (2008): 'Environmental economic geography', Geography Compass 2 (3): 831-850.

HEALY, S. (2009): 'Economies, alternative', in KITCHEN, R. and THRIFT, N. (eds): The International Encyclopedia of Human Geography, vol. 1. Elsevier, Oxford, pp. 338-344.

HELFRICH, S. and HEINRICH-BÖLL-STIFTUNG (eds) (2012): Commons. Für eine neue Politik jenseits von Markt und Staat. Transcript, Bielefeld.

HODSON, M. and MARVIN, S. (2012): 'Mediating low-carbon urban transitions? Forms of organization, knowledge and action', European Planning Studies 20 (3): 421-439.

HUBER, M. T. (2010): 'Hyphenated geographies: the deindustrialization of nature-society geography', Geographical Review 100 (1): 74-89.

JACKSON, T. (2009): Prosperity without Growth: Economics for a Finite Planet. Earthscan, London.

JACKSON, T. (2011): 'Societal transformations for a sustainable economy', Natural Resources Forum 35 (3): 155-164.

JORBERG, T. (2010): 'Finanzmärkte und Aufgaben der Banken', in SEIDL, I. and ZAHRNT, A. (eds): Postwachstumsgesellschaft. Konzepte für die Zukunft. Metropolis, Marburg, pp. 145-153.

KERSCHNER, C. (2010): 'Economic de-growth vs. steady-state economy', Journal of Cleaner Production 18 (6): 544-551.

KLAGGE, B. and BROCKE, T. (2012): 'Decentralized electricity generation from renewable sources as a chance for local economic development: a qualitative study of two pioneer regions in Germany', Energy, Sustainability and Society 2 (1): 1-9.

KNOX-HAYES, J. and HAYES, J. (2014): 'Technocratic norms, political culture and climate change governance', Geografiska Annaler: Series B, Human Geography 96 (3): 261-276.

KOSOY,N.,BROWN,P.G.,BOSSELMANN, K.,DURAIAPPAH, A., MACKEY, B., MARTÍNEZ-ALIER, J., ROGERS, D. and THOMSON, R. (2012): 'Pillars for a flourishing Earth: planetary boundaries, economic growth delusion and green economy', Current Opinion in Environmental Sustainability 4 (1): 74-79.

LATOUCHE, S. (2006): Le pari de la décroissance. Fayard, Paris.

LATOUCHE, S. (2010): 'Degrowth', Journal of Cleaner Production 18 (6): 519-522.

LINDENBERG, M. (2002): 'Measuring household livelihood security at the family and community level in the developing world', World Development 30 (2): 301-318.

LOVELOCK, J. (1979): Gaia: A New Look at Life on Earth. Oxford University Press, Oxford.

MANZINI, E. and VEZZOLI, C. (2002): Product-Service Systems and Sustainability: Opportunities for Sustainable Solutions. Division of Technology Industry and Economics, United Nations Environment Programme, Paris.

MATTHEWS, J. A. (2011): 'Naturalizing capitalism: the next Great Transformation', Futures [London] 43 (8): 868-879.

MCCAULEY, S. M. and STEPHENS, J. C. (2012): 'Green energy clusters and socio-technical transitions: analysis of a sustainable energy cluster for regional economic development in Central Massachusetts, USA', Sustainability Science 7 (2): 213-225.

MEADOWS, D. H., MEADOWS, D. L., RANDERS, J. and BERHENS, W. W., III (1972): The Limits to Growth: A Report for the Club of Rome's Project on the Predicament of Mankind. Universe Books, New York.

MONT, O. K. (2002): 'Clarifying the concept of product-service system', Journal of Cleaner Production 10 (3): 237-245.

MOULAERT, F. and AILENEI, O. (2005): 'Social economy, third sector and solidarity relations: a conceptual synthesis from history to present', Urban Studies 42 (11): 2037-2053.

NEWELL, P. (2012): Globalization and the Environment: Capitalism, Ecology and Power. Polity, Cambridge.

NORTH, P. (2005): 'Scaling alternative economic practices? Some lessons from alternative currencies', Transactions of the Institute of British Geographers NS 30 (2): 221-233.

NORTH, P. (2010): Local Money: How to Make it Happen in Your Community. Transition, Totnes.

OCAMPO, J. A. (2011): 'The transition to a green economy: benefits, challenges and risks from a sustainable development perspective: summary of background papers'. Report by a Panel of Experts to Second Preparatory Meeting for United Nations Conference on Sustainable Development, Division for Sustainable Development UN-DESA, UNEP, UN Conference on Trade and Development, New York.

OECD (2011): How's Life? Measuring Well-being. OECD Publishing, Paris.

OSTROM, E. (1990): Governing the Commons: The Evolution of Institutions for Collective Action. Cambridge University Press, Cambridge.

P2P FOUNDATION (2012): 'Synthetic overview of the collaborative economy', Stichting Peer to Peer Alternatives, Amsterdam [online]. URL http://p2p.coop/files/reports/collaborativeeconomy-2012.pdf [accessed 12 March 2013].

PAECH, N. (2010): 'Eine Alternative zum Entkopplungsmythos: Die Postwachstumsökonomie', Humane Wirtschaft (5): 12-15.

PATCHELL, J. and HAYTER, R. (2013): 'Environmental and evolutionary economic geography: time for EEG ${ }^{2}$ ?', Geografiska Annaler: Series B, Human Geography 95 (2): 111-130.

REDCLIFT, M. (2009): 'The environment and carbon dependence: landscapes of sustainability and materiality', Current Sociology 57 (3): 369-388.

RIPPIN, N. (2012): 'Wachstum für alle?', Aus Politik und Zeitgeschichte 62 (27-28): 45-51.

ROTHENBERG, S. (2007): 'Sustainability through servicizing', MIT Sloan Management Review 48 (2): 82-91.

SCHOT, J. and GEELS, F. W. (2008): 'Strategic niche management 
and sustainable innovation journeys: theory, findings, research agenda, and policy', Technology Analysis and Strategic Management 20 (5): 537-554.

SEN, A. (1999): Development as Freedom. Oxford University Press, Oxford.

SEYFANG, G. and LONGHURST, N. (2013): 'Desperately seeking niches: grassroots innovations and niche development in the community currency field', Global Environmental Change 23 (5): 881-891.

SHOVE, E. and WALKER, G. (2010): 'Governing transitions in the sustainability of everyday life', Research Policy 39 (4): 471-476.

SORRELL, S. (2007): The Rebound Effect: An Assessment of the Evidence for Economy-Wide Energy Savings from Improved Energy Efficiency. Report by the Sussex Energy Group for the Technology and Policy Assessment function of the UK Energy Research Centre, London.

SOYEZ, D. and SCHULZ, C. (2008): 'Facets of an emerging environmental economic geography (EEG)', Geoforum 39 (1): $17-19$.

STIGLITZ, J., SEN, A. and FITOUSSI, J.-P. (2009): Report by the Commission on the Measurement of Economic Performance and Social Progress, September [online]. URL http://www. stiglitz-sen-fitoussi.fr/documents/rapport_anglais.pdf [accessed 7 May 2012].

SWYNGEDOUW, E. (2010): 'Apocalypse forever? Post-political populism and the spectre of climate change', Theory, Culture and Society 27 (2-3): 213-232.

TRUFFER, B. (2008): 'Society, technology, and region: contributions from the social study of technology to economic geography', Environment and Planning A 40 (4): 966-985.

TRUFFER, B. and COENEN, L. (2012): 'Environmental innovation and sustainability transitions in regional studies', Regional Studies 46 (1): 1-21.

UNEP (2011): Towards a Green Economy: Pathways to
Sustainable Development and Poverty Eradication. United Nations Environment Programme, Nairobi.

VIARDOT,E. (2013): 'The role of cooperatives in overcoming the barriers to adoption of renewable energy', Energy Policy 63: 756-764.

VON WEIZSÄCKER, E., HARGROVES, K., SMITH, M., DESHA, C. and STASINOPOULOS, P. (2009): Factor Five: Transforming the Global Economy through $80 \%$ Improvements in Resource Productivity. Earthscan, London.

VON WEIZSÄCKER, E., LOVINS, A. B. and LOVINS, L. H. (1998): Factor Four: Doubling Wealth, Halving Resource Use - A Report to the Club of Rome. Earthscan, London.

VOß, J.-P. (2007): 'Innovation processes in governance: the development of "emissions trading" as a new policy instrument', Science and Public Policy 34 (5): 329-343.

WALKER, G. and SHOVE, E. (2007): 'Ambivalence, sustainability and the governance of socio-technical transitions', Journal of Environmental Policy and Planning 9 (3-4): 213-225.

WALTHER, O., SCHULZ, C. and DÖRRY, S. (2011): 'Specialized international financial centres and their crisis resilience: the case of Luxembourg', Geographische Zeitschrift 99 (2-3): 123-142.

WCED (1987): Our Common Future. World Commission on Environment and Development. Oxford University Press, Oxford.

WOLSINK, M. (2011): 'The research agenda on social acceptance of distributed generation in smart grids: renewable as common pool resources', Renewable and Sustainable Energy Reviews 16 (1): 822-835.

WORLDWATCH INSTITUTE (ed.) (2012): State of the World 2012: Moving Toward Sustainable Prosperity. Island Press, Washington, DC.

ZADEMACH, H.-M. and HILLEBRAND, S. (eds) (2013): Alternative Economies and Spaces: New Perspectives for a Sustainable Economy. Transcript, Bielefeld. 